\section{Three Buckets and Eight Strategies: Recruiting, Supporting, and Retaining a Racially Diverse Special Education Teacher Workforce}

\author{
AUTHORS \\ LaRon A. Scott and \\ William Proffitt
}

Journal of Special

Education Preparation

1(2), 16-23

(C) 2021 Scott and Proffitt

Licensed with CC-BY-NC-ND 4.0

License

DOI: 10.33043/JOSEP.1.2.16-23

openjournals.bsu.edu/JOSEP

\title{
ABSTRACT
}

Cultivating a racially diverse special education teacher workforce is critical to the success of students with disabilities, particularly students of color with disabilities. We examine the literature and provide suggestions for recruiting, supporting, and retaining special education teacher candidates of color. Specifically, we present a vignette that highlights the decision-making process of a Black male on a journey to become a special education teacher. We propose recruitment strategies (e.g., anti-racist mission and vision statements), support strategies (e.g., racial affinity groups), and retention strategies (e.g., adopting anti-racist curriculum) that Institutions of Higher Education must consider to promote efforts to diversify the special education teacher workforce.

\section{KEYWORDS}

Special education, teachers of color, teacher recruitment, teacher retention

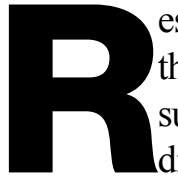
esearchers have discussed the importance of recruiting, supporting, and retaining a diverse special education teacher (SET) workforce to improve the representation of SETs of color in K-12 schools (e.g., Billingsley et al., 2019; Cormier, 2020; Scott, 2016). Ultimately the goal is to positively influence the educational experiences of K-12 students, especially the academic, social, and emotional well-being of students of color with disabilities (Cormier et al., 2020; Scott \& Alexander, 2019; Scott et al., 2021). However, an underrepresentation of SETs of color occurs compared to the overrepresentation of students of color in special education (Billingsley et al., 2019). Researchers have proposed strategies for recruiting, supporting, and retaining more SETs of color to improve the ratio of student-teacher racial match in special education (Cormier \& Scott, 2021; Scott \& Alexander, 2019). Yet, the work is not always emphasized in a practical way that leaders of Institutions of Higher Education (IHEs) can use to create new practices, procedures, and policies to better recruit, support, and retain individuals in their respective organizations. We argue that IHEs play a major role in recruiting, supporting, and retaining future teacher educators. Therefore, IHEs must engage in efforts to adopt strategies that lead to diversifying the teacher workforce, and this also means the SET workforce.

Based on the currently available research, this article will provide investigators, leaders of IHEs, and policymakers with practical strategies and guidelines for recruiting, supporting, and retaining special education teacher candidates of color (SETCOC). To simplify and get the most out of the effort, strategies and guidelines are organized into three buckets for recruiting, supporting, and retaining SETCOC. Figure 1 shows the three buckets and provides an overview of eight strategies that IHE stakeholders should consider when recruiting, supporting, and retaining SETCOC. A vignette is provided about a Black man who is considering a career in special education, demonstrating how these strategies can be employed. Following this individual, we put forward practical strategies faculty, staff, policymakers, 
FIGURE 1: Special Educators Teacher Candidates of Color Recruitment,

Support, and Retention Buckets and Essential Strategies

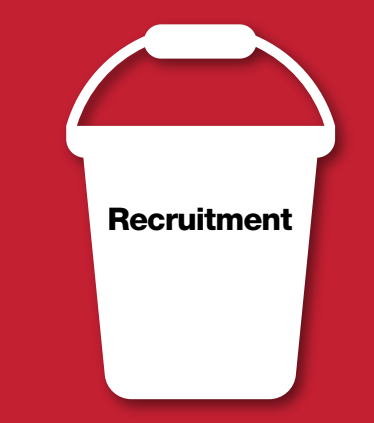

Anti-racist Mission and Vision Statements

Representation from Faculty and Teacher

Candidates of Color in

Special Education

Assorted Pathway

Programs

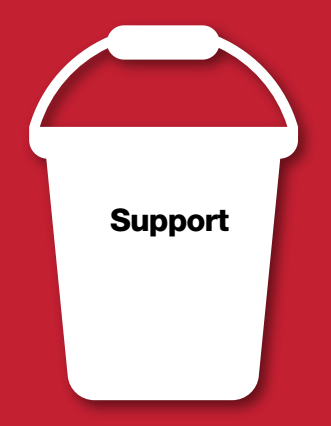

Affinity Groups

Racially respective support system

Tuition Support

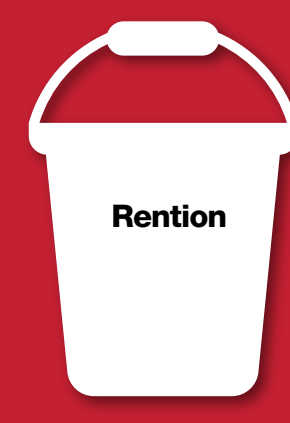

Adopting Antiracist Curriculum and

Pedagogical Knowledge

Erasing the Burden and other stakeholders can follow to recruit, support, and retain SETCOC.

\section{Meet Kevin!}

Kevin is a potential career switcher. He is preparing to leave his 10-year career as a juvenile justice officer to pursue his dream of becoming a SET. Specifically, his experience in working with youth in the justice system has sped up his desire to become a SET. Kevin wants to interrupt the school-to-prison pipeline for students of color, some of whom are from the community in which he lives. He wants to reach this youth population before they are inequitably forced into the justice system and Kevin believes that teaching is the next career path to accomplish this goal. He is especially passionate about working with students of color with disabilities, since members of this group have been more prevalent in his encounters as a juvenile justice officer. Kevin believes it is the right time to make his career move because he just learned that a SET at the middle school in his community is retiring soon, opening up a position in the near future. Although Kevin would prefer to attend the Historically Black College from where he received his bachelor's degree, the college does not have a special education preparation master's degree program. Consequently, he is considering attending the local IHE, a predominately White institution, but he wants to be sure that the values of the institution are in alignment with his goals before enrolling. Specifically, he is looking for programs where he can be engaged in a diverse learning experience that include academic and social experiences that center dismantling inequities for marginalized students, specifically students of color with disabilities. Kevin also wants to experience a program that engages him, encourages him, and accepts and supports his thoughts and experiences as a Black man. With little money to pursue this dream, Kevin sets out to explore whether he can become a SET.

\section{The Recruitment Bucket}

To identify whether the IHE program is the best fit for him, Kevin begins by investigating the ways the leaders at his local IHE are pursuing "people who look like him" into the organization. Kevin's journey begins by investigating what ways the organizational leaders conduct outreach to target SETCOC. This journey is called the "Recruitment Bucket."

\section{Anti-Racist Mission and Vision Statements}

According to the literature, IHE leaders should consider whether their mission, vision, and social justice statements explain their positions on how systemic and structural discrimination issues are addressed in their organizations (Scott, 2018). For example, Scott (2018) interviewed 10 SETCOC enrolled in a special education teacher education program at a predominately White IHE. Scott found that many of the SETCOC were attracted to the program because the mission statement at the IHE aligned with their interest as social justice advocates. Mission, vision, and social justice statements can often be a SETCOC first impression of an organization, and from the statements, organizational leaders offer ripe opportunities to describe their stances on broad societal and structure issues. These stances can include how justice against racism, ableism, and other disparities that challenge minoritized K-12 students with disabilities is achieved. Statements that are used to incorporate a clear mandate against systemic and structural issues may be used to attract a more racially diverse group of SETCOC, including Black special educators (Scott, 2018; Scott \& Alexander, 2019). Explicit statements on the issues are a way for racially diverse educators to understand how diversity, equity, and inclusion positions are incorporated into systems. The statements indicate where the leaders of the systems will invest in learning from faculty and staff, engage with peers and colleagues, implement practices, conform to school climate, and understand learning conditions (Scott, 2018). Table 1 shows how this particular strategy, along with guiding questions from special education 
IHE faculty members and staff, can be used to interrogate whether an IHE's mission statement centers on anti-racist components. Additionally, Table 1 shows the remaining strategies, questions, and snippets for practical application of each strategy.

Fortunately, when Kevin explored the mission and vision statement for the special education program at the local IHE, they communicated an intersection of anti-racist and anti-ableism positions and described ways that the program leaders sought to eradicate these structural and systemic issues. For Kevin, the strong statements were an attraction, and he was motivated to apply to the program. However, he did have additional questions for the faculty and staff members in the program because he wanted to be sure that the mission and vision of the program aligned with practices that the program leaders followed.

\section{Representation from Faculty and SETCOC in Special Education}

After applying, Kevin received a call inviting him for an in-person interview to the program. He was excited that his dream had moved forward to the next step, but nervous about what the faculty members and teacher candidates were like in the College of Education within the IHE. Would teacher candidates and faculty members be racially diverse? Racial diversity was important to Kevin because he learned from reading about attending predominately White institutions that many times students of color enrolled in programs struggled with isolation and belongingness on the campuses (Strayhorn, 2012), including in special education programs (Scott, 2018). Although he applied to the program, he was still uncertain as to whether he was going to attend. He was concerned if there would be SETCOC and faculty members who "looked like him." His trepidation at this point was whether there was racial diversity in the program that reflected the mission and vision he read. If not, then he would know this was not the program and perhaps not even the career for him. He eventually decided to move forward in the application process with the program.

To eradicate fear for individuals like Kevin, leaders at IHEs must consider the racial diversity of the faculty members and SETCOC within their programs. Having diverse representation of faculty members and SETCOC in special education programs has been linked to recruiting potential SETCOC into the programs (Scott, 2018; Scott \& Alexander, 2019). Researchers have indicated that similar qualities like race can positively influence interviews because for some candidates, shared identity may serve as a proxy for shared or similar beliefs and experiences (Krysan \& Couper, 2003). Candidates may speak more candidly with faculty and teacher candidates who they believe understand the candidates' lived realities and is sensitive to the candidates' beliefs and feelings about the world (Krysan \& Couper, 2003). It is safe for a candidate to assume that faculty and teacher candidates who experience similar realities as them will — at the least - understand that candidate's social position and respect their perspective on identity-related issues.

A program that has racially diverse faculty members and teacher candidates who can become involved in the recruitment and interview process of potential candidates may offer Kevin and others the opportunity for open dialogue regarding the candidates' goals for the program. The suggestion to have racially diverse faculty members and SETCOC involved in the recruitment/interviewing process is not meant to exploit the individuals in programs. Instead, the call is for IHE leaders to ensure that racial diversity is a priority in hiring special education faculty members and in enrolling SETCOC into the program so that diverse representation is present and valued. Recent literature showed that faculty members and SETCOC can serve as effective recruitment sources (e.g., recruitment, hiring, and even mentoring) that affirm racially diverse candidates like Kevin that racial diversity matters and that a space exists for them in the program and in the profession (Scott, 2019; Scott \& Alexander, 2019). Leaders of IHEs must be aware though that any additional responsibilities for faculty members and SETCOC in their programs to engage in recruitment can cause an overburden that can lead to burnout (Scott, 2016; Scott, 2018). Therefore, relieving those individuals of other duties and responsibilities and compensating them for their effort in the recruitment process should be considered.

\section{Assorted Pathway Programs}

Kevin was impressed with the interview, which included two faculty members, one of whom was a person of color. Also, his meeting included five SETCOC. He was closer to agreeing to attend the program, though he was still undecided if he would leave his job full-time. He wanted to know if options were available to attend the program while he worked full-time or part-time. Kevin also remembered that his dream position at the local middle school was opening in less than two years, so completing a program at an accelerated pace was a priority. For that reason, he wondered if the special education program offered nontraditional pathways that suited his lifestyle.

Developing creative and multiple pathways to obtain SET certification has garnered recent interest (Carver-Thomas, 2018; Scott, 2019). Examples of creative and nontraditional pathway programs include Grow Your Own programs, traditionally seen as community-driven programs designed to target community members (e.g., parents, paraprofessionals) who will be trained to become teach- 
ers (Gist, 2019). Grow Your Own programs are considered effective routes to recruit teacher candidates into the teacher education profession (Gist, 2019; Gist et al., 2019), including special education (Scott, 2019; Scott \& Alexander, 2019 2). Similarly, residency programs have been found to attract teacher candidates of color and provide them with spaces that affirm their identity and mission (Watson et al., 2015). Residency programs are generally described as medical model, alternative pathway programs, grounded in clinical training that includes an apprenticeship for one full year under the supervision of a master teacher (Guha et al., 2017). This alternative model prepares teacher candidates, typically for hard-to-staff communities, and is often spotlighted for recruiting higher percentages of teachers of color into teacher training programs (Guha et al., 2017).

Other creative and nontraditional pathways include virtual programs that are used to offer flexibility to teacher candidates of color. Specifically, SETCOC have suggested that the nontraditional pathway programs are an attraction, particularly for working adults (Scott, 2019). Thus, leaders of IHEs should consider how to create alternative pathway programs from within local communities at their respective organizations and identify ways to partner with people of color to design these nontraditional pathway programs that meet their particular needs. Table 1 shows additional guiding questions and examples of program types that IHE leaders can consider for SETCOC seeking to enroll in special education programs.

\section{The Support Bucket}

In previous empirical research used to investigate SECOC, participants expressed that having supports while enrolled in IHEs were significant factors that increased their retention (Scott, 2018). Providing planned and deliberate supports for SETCOC can have a direct connection with having a positive experience in special education preparation programs and careers that may lead to greater retention of these educators (Scott, 2018; Scott \& Alexander, 2019). Accordingly, the next section is called the "Support Bucket."

As luck would have it, the IHE leaders had an accelerated pathway program that was the right fit for Kevin. He enrolled and started the program. Soon, Kevin learned that although the program was diverse, SETCOC were disparately outnumbered, although not unusual for special education preparation programs (Cormier et al., in press). Kevin was concerned about what his experience would be like while enrolled in this program at the predominately White institution. He wondered if the program leaders had considered developing a holistic experience for SETCOC, and this meant that they were not the only person discussing issues of structural and systemic issues of race in special education, and whether support groups were on campus for IHE students of color at a predominately White institution. He wanted to know what the supports were because having the supports would be critical for ensuring him a positive experience in the program.

\section{Affinity Groups}

In simplest terms, affinity groups refer to individuals grouping together and networking based on common action, activism, ideology, or interest (Pour-Khorshid, 2018). Such groups are an increasingly used tool for cultivating a diverse teacher workforce, including providing supports for reducing trauma and supporting teacher candidates' social, emotional, personal and professional needs (Pour-Khorshid, 2018). Instead of the standard business organization model of affinity groups, we are proposing racial affinity groups based on belongingness, hope, engagement, inspiration, advocacy, and connectedness. Research- ers have highlighted the importance of bringing racially diverse SETs together across common interests to support their journeys throughout the SET education pipeline (Scott \& Alexander, 2019).

Racial affinity groups may offer ways to invigorate and inspire educators, particularly as many of these educators face racialized barriers in preparation programs (Pour-Khorshid, 2018; Scott, 2019) and in their teaching careers (Scott et al., 2021). The development of racial affinity groups has been linked to increased productivity of teacher candidates of color during their preparation programs (Kohli, 2018), and implicitly with Black male SETs, as mechanisms to support them while enrolled in their preparation programs and across their K-12 careers (Scott \& Alexander, 2019). One indication that racial affinity groups may be effective was shown in a study about strategic ways to recruit and retain Black male SETCOC by Scott \& Alexander when one teacher candidate commented:

It would be so much easier to make a decision about a program if you could relate to the people in your program and they could assist you with the service and resources that applied to your role and responsibility. (pg. 8)

Similarly, in a study by Kohli (2018), participants noted the influence of racial affinity groups in recruiting, supporting, and retaining during the teacher educator preparation process. For Black teacher educator candidates in special education, particularly, providing safe spaces can help them navigate and manage some of the challenges they face during the teacher education pipeline (Scott, 2018).

\section{Racially Respective Mentoring/Support System}

Racial and ethnic representation in IHEs is important for teacher candidates of color to promote their academic success, academic support, and career support (Scott, 2019; Strayhorn, 2012). 
Teacher candidates of color can often feel alienated in IHE programs as samerace faculty members and IHE student representation is not always congruent, particularly at predominately White institutions (Strayhorn, 2012). Researchers found that SETCOC in special education preparation programs note that same-race faculty and peers are an important factor linked to their retention (Scott, 2019; Scott \& Alexander, 2019). For example, a teacher candidate of color able to receive mentoring and coaching support from a same-race professor who may be able to understand the cultural context of their challenges may be better equipped to relate and offer guidance and support to overcome issues. However, this strategy should not be used as a recommendation that teacher candidates of color should only receive same-race mentoring support, but more so used as a form of support that indicates the importance of representation in mentoring (Scott, 2019; Scott \& Alexander, 2019).

\section{Tuition Support}

Financial support (e.g., scholarships and stipends) for enrolling in IHE special education preparation programs may boost the number of SETCOC interested in teaching in special education. Offering tuition support as an effective strategy to recruit SETCOC for special education programs can offset the costs of teacher preparation, a problem that teachers of color often cite as a barrier for enrolling and completing teacher education programs (Carver-Thomas, 2018; Scott, 2019). Consider, for instance, that the median wealth of Black families $(\$ 24,000)$ is nearly eight times less than that of White families $(\$ 188,200$; Moss et al., 2020). Some Black families have little to no money to bail themselves out of emergencies, much less can they afford to increase their debt load. Tuition support has been aligned with research that consistently indicates the rising costs of tuition as a barrier, so providing financial incentives are valid ways to recruit and retain teachers of color (Carver-Thomas, 2018; Scott, 2019).

When a teacher candidate of color is receiving financial support in their program, they may be able to attend the IHE program on a full-time basis and focus on becoming effectively prepared SETs. In the illustration regarding Kevin as a potential career switcher, the only reason he is considering staying on his job fulltime or part-time is based on his inability to maintain his home-life balance (e.g., rent, car payment) if he is not earning some form of income. Kevin would like to enroll full-time in the IHE special education training program but risks depleting his savings or being forced to take out a large federal loan to quit his job and concentrate on his training. If Kevin was offered scholarships or a stipend to enroll in the program, he could use some money from his savings for living expenses while in his training, or he may be able to work part-time while training. If he is not offered a scholarship to attend the program, he is considering staying with his current job and even postponing his dream of becoming a SET. Additional guiding questions and examples to consider when applying the affinity groups, support systems, and tuition constructs are in Table 1.

\section{The Retention Bucket}

Literature based on retaining SETCOC indicate that strategies must be prioritized and in place to ensure educators remain in programs for the long term (Scott, 2018). The next set of strategies is focused on keeping SETCOC like Kevin and is titled the "Retention Bucket."

Kevin is becoming more comfortable and stable in the new IHE program. The program leaders offered to fully pay his tuition and added a healthy stipend for him to attend the program based on a new federal grant received from the Office of Special Education Program, which provides financial support for teacher candidates in special education with a particular focus on recruiting educators of color. Kevin is thrilled that he will receive full-tuition support, including a healthy monthly financial stipend that will allow him to leave his job to focus full-time on his training. Additionally, Kevin will be mentored by a faculty member of color with whom he is excited to engage. Leaders of the College of Education also offered a IHE student-led affinity group focusing on anti-racism that Kevin joined. Although he is feeling more "at home" in the college and program, he wonders whether his optimism will remain, as he has heard that attrition rates for educators of color are high at predominately White institutions (McClain \& Perry, 2017).

\section{Adopting Anti-Racist Curriculum and Pedagogical Knowledge}

Anti-racist education generally refers to examining and addressing systemic and structural racism, ideologies, and beliefs (Carr \& Lund, 2009) that can keep the rights of children and the empowerment of positive identity at the forefront of the development and delivery of curricula, practice, and pedagogical transfer of information (Derman-Sparks \& Edwards, 2010; Derman-Sparks et al., 2015). Many SETCOC have voiced that having access to more diverse content in their preparation programs would compel them to remain in their respective teacher education programs (Scott, 2018; Scott \& Alexander, 2019). By adopting anti-racist education curriculum, frameworks, and pedagogical approaches in IHEs, SETCOC may feel more autonomous in teaching the material once they exited their programs (Scott \& Alexander, 2019). The SETCOC have a "desire to teach curriculum that would be more culturally engaging to students with disabilities" (Scott \& Alexander, 2019, p. 243). Opportunities to engage in learning and practice using diverse forms of cur- 


\section{TABLE 1: EXAMPLES OF 3 BUCKETS STRATEGIES}

\begin{tabular}{|c|c|c|c|}
\hline BUCKET & STRATEGY & GUIDING QUESTIONS & SPECIFIC EXAMPLE \\
\hline Recruitment & $\begin{array}{l}\text { Anti-racist mission } \\
\text { and vision statements }\end{array}$ & $\begin{array}{l}\text { Does your mission and vision statement explicitly } \\
\text { emphasize a commitment to racial equity? The } \\
\text { intersection of race and ability? }\end{array}$ & $\begin{array}{l}\text { We are committed to eradicating barriers for } \\
\text { students of color with disabilities that are grounded } \\
\text { in systemic and structural racism, ableism, and other } \\
\text { forms of racial disparities. }\end{array}$ \\
\hline Recruitment & $\begin{array}{l}\text { Representation from } \\
\text { faculty and students } \\
\text { of color in special } \\
\text { education }\end{array}$ & $\begin{array}{l}\text { Have we targeted the hiring of faculty of color } \\
\text { in job searches? How have our recruitment } \\
\text { efforts improved ways to attract racially diverse } \\
\text { candidates in our programs? }\end{array}$ & $\begin{array}{l}\text { Establishing departmental and program metrics for } \\
\text { increasing faculty and students of color in special } \\
\text { education programs. }\end{array}$ \\
\hline Recruitment & $\begin{array}{l}\text { Assorted pathway } \\
\text { programs }\end{array}$ & $\begin{array}{l}\text { How has our traditional pathway program excluded } \\
\text { educators of color? Can an alternative pathway be } \\
\text { designed that offers rigor and opportunity for all } \\
\text { candidates but especially educators of color? }\end{array}$ & $\begin{array}{l}\text { By designing a residency program in collaboration } \\
\text { with local urban school districts, we can establish } \\
\text { recruitment metrics for educators of color while } \\
\text { improving our relationship with the local community. }\end{array}$ \\
\hline Support & Affinity groups & $\begin{array}{l}\text { Are there common interest programs that center } \\
\text { race across the university that special educators of } \\
\text { color can participate in? Can providing an affinity } \\
\text { group create a "safe space" for special educators } \\
\text { of color in my program? }\end{array}$ & $\begin{array}{l}\text { Polling former and current special educators of color } \\
\text { on what topics these educators would like to gather } \\
\text { to support a common goal. }\end{array}$ \\
\hline Support & $\begin{array}{l}\text { Racially respective } \\
\text { support system }\end{array}$ & $\begin{array}{l}\text { How is our mentoring program for students in } \\
\text { our program intentionally centering the racialized } \\
\text { challenges special educators of color may face? } \\
\text { What experience do our faculty have with serving } \\
\text { as role models and guiding special educators of } \\
\text { color? }\end{array}$ & $\begin{array}{l}\text { Establishing a process where mentoring matches } \\
\text { are intentional and includes a process for feedback } \\
\text { and developing interpersonal relationships with } \\
\text { special educators of color. }\end{array}$ \\
\hline Support & Tuition support & $\begin{array}{l}\text { Have we sought out resources at the state or } \\
\text { federal level that will help with providing financial } \\
\text { supports to special educators of color? Are there } \\
\text { ways that we can advocate for modified tuition for } \\
\text { special educators, particularly those of color? }\end{array}$ & $\begin{array}{l}\text { Faculty pursuing funding through the Office of } \\
\text { Special Education Programs, and specifically } \\
\text { designing the application that targets the recruitment } \\
\text { and supports of potential special educators of color. } \\
\text { Funds for living costs and tuition, travel, and other } \\
\text { expenses will be covered. }\end{array}$ \\
\hline Retention & $\begin{array}{l}\text { Adopting anti- } \\
\text { racist curriculum } \\
\text { and pedagogical } \\
\text { knowledge }\end{array}$ & $\begin{array}{l}\text { Have we examined our curriculum for cultural } \\
\text { diversity? In what ways does our curriculum } \\
\text { uphold whiteness? }\end{array}$ & $\begin{array}{l}\text { Replacing textbooks and articles that have all-white } \\
\text { authors or do not center race as a positive with text } \\
\text { and articles from more racially diverse authors. }\end{array}$ \\
\hline Retention & Erase the burden & $\begin{array}{l}\text { Are we paying close attention to who speaks up } \\
\text { in class when issues of race are addressed? How } \\
\text { can faculty create a space where all students are } \\
\text { discussing race so that special educators of color } \\
\text { do not feel isolated in their advocacy? }\end{array}$ & $\begin{array}{l}\text { Faculty encourages discussion by all students to } \\
\text { discuss issues of race. }\end{array}$ \\
\hline
\end{tabular}




\section{ABOUT THE AUTHORS}

\section{LaRon A. Scott}

LaRon A. Scott, EdD, is an associate professor of special education, as well as the executive director of the Minority Educator Recruitment, Retention, and Equity Center at Virginia Commonwealth University. His research focuses on attracting, preparing, and retaining underrepresented special education teacher educators. He also focuses on postsecondary transition experiences of Black youth with IDD.

\section{William Proffitt}

William Proffitt, M.Ed., is a doctoral candidate in the Department of Special Education at the University of Kansas. He explores and writes about the intersections of race, class, gender, disability, and justice. Specifically, his work foregrounds the experiences and voices of Black boys with and without disability labels, their families, and the communities in which they are embedded. He seeks to improve the life experiences of all students, especially those from historically marginalized backgrounds, by re-mediating the practices of schools and education professionals. riculum in training programs can provide an experience where Whiteness is not solely centered, a point that SETCOC interviewed in literature noted they would appreciate (Scott \& Alexander, 2019). In the example, once graduated, Kevin can apply the anti-racist content and pedagogical approaches that he learned in his teacher preparation program at the middle school he desires to work.

SETCOC in special education preparation programs are often driven by programs that offer social justice advocacy stances (Scott, 2018). Programs that center social justice advocacy stances in their curriculum, particularly curriculum that is diverse and has implications for advocacy to support students of color with disabilities (Scott, 2018), provide ways to engage SETCOC and hopefully retain them. As the teacher candidates have indicated, having diverse content is important for them transferring to K-12 students when they become teachers of records (Scott, 2018; Scott \& Alexander, 2019). Once Kevin graduates from his program, he will be equipped to engage his students in anti-racist and culturally responsive content by offering them a combination of teaching, pedagogy, practices, and instructional materials that he learned in his teacher preparation program.

\section{Erase the Burden}

Erase the burden refers to the "tax" that SETCOC often pay because they are one of only a few in their teacher preparation programs. For the SETCOC, this often means that they are put in a position to serve as cultural brokers or Black ambassadors in dialogue where issues of race are discussed (Borrero et al., 2016; Scott et al., 2021). These practices reinforce the notion that people of color - the prime victims of racism and its intersecting oppressions - bear the responsibility for disrupting systemic racism while White people can stand idly on the sidelines (Matias \& Mackey,
2016). These are unfair conditions for educators of color, and specifically for SETs of color who often cited this tax (Scott et al., 2021). The tax can cause stressful conditions that can lead to role ambiguity, thoughts about attrition (Scott et al., 2021), and other questions about how SETCOC fit in their IHE preparation programs or careers (Scott, 2018). Faculty and other program staff members must remain sensitive to these issues. Furthermore, program leaders must ensure that a climate exists in which these issues are eradicated.

As Kevin moves forward in his career, although he anticipated advocating and speaking up for social justice issues, he does not want to be the only educator speaking up and doing this work. He did not anticipate that being the only Black teacher candidate would mean that he was always interjecting a comment about race and did not feel supported by his peers and faculty members when issues of race are raised in course discussions or other programmatic areas. He was surprised that some of the White faculty members did not feel equipped to have open-minded discussion on sociocultural issues, including race, particularly when the status quo of thinking was involved. He wonders if he made the right decision and whether he will stay the full length of the program. Fortunately, he can talk with his faculty mentor and the peers in his affinity group to create an action plan to address the issue. Although it is an extra step he has to take that others teacher candidates (e.g., White teacher candidates) may not, he feels better about the strategies his mentor and peers give him and decided to stay and finish out his program. Kevin thinks he is one of the lucky SETCOC who has such a support system, and he wonders what the outcome for him would have been if these strategies were not in place at the IHE.

\section{Conclusion}

It is important to note that many of the 
strategies that we propose provide an opportunity for cross-institutional collaboration. The strategies that we propose are in sequential order based on the vignette and prospective path of a SETCOC who would enroll in a teacher education program before becoming employed in a school district. However, both IHEs and school districts must consider these strategies independently, and in many cases collaborate to adopt comprehensive strategies to recruit, support, and retain a racially diverse SET workforce. For example, it is also critically important that school districts develop and promote anti-racist missions, vision, and social justice statements. Furthermore, IHEs and school districts have the potential to work collaboratively to develop assorted pathway programs and together address ways to supplement tuition or relieve financial burdens for SETCOC. For instance, in developing Grow Your Own programs, IHEs and school districts should consider working together to create assorted pathway programs that reduce tuition and improve the retention of these teachers. We posit that collaborating in many cases will generate creative planning and provide comprehensive ideas for recruiting, supporting, and retaining SETs of color.

The focus of this article is on providing strategies for recruiting, supporting, and retaining SETCOC in IHE special education preparation programs. For Kevin, a potential Black male SET, the strategies are important for his journey in becoming a SET. The implication for growing a more racially diverse SET workforce is contingent on how well stakeholders can enact the strategies within the three buckets and even develop additional strategies within the buckets. Although the three buckets of recruiting, supporting, and retaining are described as a focus of recent literature (Carver-Thomas, 2018; Scott, 2018, 2019; Scott \& Alexander, 2021), we do not contend that the strategies list- ed as a part of the buckets in this paper are the only effective strategies. Further, we stress that experts in the educational field should investigate more ways to hear from SETCOC regarding their needs. Otherwise, long-term issues with retaining SETCOC will continue.

\section{References}

Billingsley, B. S., Bettini, E. A., \& Williams, T. O. (2019). Teacher racial/ethnic diversity: Distribution of special and general educators of color across schools. Remedial and Special Education, 40(4), 199-212. https://doi. org $10.1177 / 0741932517733047$

Borrero, N. E., Flores, E., \& de la Cruz, G. (2016). Developing and enacting culturally relevant pedagogy: Voices of new Black teachers. Equity \& Excellence in Education, 49(1), 27-40. https://doi.org/10.1080/10665684.201 5.1119914

Carr, P. R., \& Lund, D. E. (2009). The unspoken color of diversity: Whiteness, privilege, and critical engagement in education. In S. R. Steinberg (Ed.), Diversity and multiculturalism: A reader (pp. 45-55). Peter Lang.

Carver-Thomas, D. (2018). Diversifying the teaching profession: How to recruit and retain teachers of color. Learning Policy Institute.

Cormier, C.J., Houston, D.A., Scott, L.A. (in press). When salt ain't enough: A critical quantitative analysis of special education and education degree production. Teacher College Record.

Cormier, C. J., \& Scott, L. A. (2021). Castaways on Gilligan's Island: Minoritized special

education teachers of color advocating for equity. TEACHING Exceptional Children, 53(3), 234-242. https://doi. org $/ 10.1177 / 0040059920974701$

Derman-Sparks, L., \& Edwards, J. O. (2010). Anti-bias education for young children and ourselves. National Association for the Education of Young Children.

Derman-Sparks, L., LeeKeenan, D., \& Nimmo, J. (2015). Leading anti-bias early childhood programs: A guide for change. Teachers College Press.

Gist, C. D. (2019). Grow your own programs and teachers of color: Taking inventory of an emerging field. Teacher Education Quarterly, 46(1), 5-8. https://www.jstor.org/ stable $/ 26558178$

Gist, C. D., Bianco, M., \& Lynn, M. (2019). Examining grow your own programs across the teacher development continuum: Mining research on teachers of color and nontraditional educator pipelines. Journal of Teacher Education, 70(1), 13-25. https://doi. org $/ 10.1177 / 0022487118787504$

Guha, R., Hyler, M. E., \& Darling-Hammond, L. (2017). The teacher residency: A practical path to recruitment and retention. American
Educator, 41(1), 31-36.

Kohli, R. (2018). Lessons for teacher education: The role of critical professional development in teacher of color retention. Journal of Teacher Education, 70(1), 39-50. https://doi. org/10.1177/0022487118767645

Krysan, M., \& Couper, M. P. (2003). Race in the live and the virtual interview: Racial deference, social desirability, and activation effects in attitude surveys. Social Psychology Quarterly, 66(4), 364-383. https://doi. org $/ 10.2307 / 1519835$

Matias, C. E., \& Mackey, J. (2016). Breakin' down Whiteness in antiracist teaching: Introducing critical Whiteness pedagogy. The Urban Review, 48(1), 32-50. https://doi.org/10.1007/ s11256-015-0344-7

McClain, K. S., \& Perry, A. (2017). Where did they go: Retention rates for students of color at predominantly White institutions. College Student Affairs Leadership, 4(1), Article 3.

Moss, E., McIntosh, K., Edelberg, W., \& Broady, K. (2020). The Black-white wealth gap left Black households more vulnerable. https://www.brookings.edu/blog/upfront/2020/12/08/the-black-white-wealth-gapleft-black-households-more-vulnerable/

Pour-Khorshid, F. (2018). Cultivating sacred spaces: A racial affinity group approach to support critical educators of color. Teaching Education, 29(4), 318-329. https://doi.org/10. 1080/10476210.2018.1512092

Scott, L.A., (2016). Where are all the black male special education teachers? Perspectives on Urban Education, 13(1), 42-48.

Scott, L.A. (2018). Recruiting and retaining Black students for special education teacher preparation inclusion programs. Inclusion, 6(2), 143-157. https://doi.org/10.1352/2326$\underline{6988-6.2 .143}$

Scott, L.A. (2019). Experience of Black male special education teachers: Are alternative licensure programs the desired route for recruitment and preparation? Education and Urban Society, 51(3), 332-350. https://doi. org $/ 10.1177 / 0013124517719971$

Scott, L.A., \& Alexander, Q. (2019). Strategies for recruiting and retaining Black male special education teachers. Remedial and Special Education, 40(4), 236-247.

https://doi.org/10.1177/0741932517732636

Scott, L.A., Brown, A., Wallace, W., Powell, C., Cormier, C. (2021). If we're not doing

it, then who? A qualitative study of Black special educators' persistence. Exceptionality. 29(3), 182-196. https://doi.org/10.1080/09362835.2 020.1850453

Strayhorn, T. L. (2012). College students'sense of belonging: A key to educational success for all students. Routledge.

Watson, A., Bristol, T., White, T., \& Vilson, J. L. (2015, July 14). Recruiting and retaining educators of color. Shanker Institute. https:// www.shankerinstitute.org/blog/recruit-

ing-and-retaining-educators-color 